\title{
Characterizing a Populated Riparian Zone
}

\author{
Darrien Yau Seng Mah \\ Department of Civil Engineering, Faculty of Engineering, Universiti Malaysia Sarawak, Kota Samarahan, \\ Sarawak, Malaysia \\ Email: ysmah@feng.unimas.my
}

Received 4 May 2014; revised 2 June 2014; accepted 12 June 2014

Copyright (C) 2014 by author and Scientific Research Publishing Inc.

This work is licensed under the Creative Commons Attribution International License (CC BY). http://creativecommons.org/licenses/by/4.0/

(C) (i) Open Access

\begin{abstract}
Developments adjacent to river, over the years, have impacted the ecological systems along riparian zones. This paper is to explore the changes occurring in a populated riparian zone. For over 35 years, the nipah swamps along the study site at the edge of Kuching city, Sarawak, Malaysia are subjected to human disturbances. Once a nipah forest is dominated by Nypa fruticans, the study site is being replaced by Sonneratia caseolaris-a mangrove forest. Both plants are indigenous to Southeast Asia region. We observe in the study site that Nypa fruticans, habitually a dominant species, is weakened when human disturbances are high, and leads to event taken over by Sonneratia caseolaris. We point out that Sonneratia caseolaris behaves intrusively rather than neighborly in disturbed systems. Here, we suggest that the plant also has high resistance towards human disturbances. This is a growing behavior contradictory to reports of Sonneratia caseolaris in natural systems.
\end{abstract}

\section{Keywords}

Mangrove, Nipah Swamp, Nypa fruticans, Sonneratia caseolaris, Urban River

\section{Background}

Human activities increasingly either degrade ecosystems, leading to harsher abiotic conditions and/or more limited dispersal of the species originally present; or introduce new species which alter the biotic environment and potentially reduce chances for system redevelopment. In both situations, novel ecosystems can be expected [1]-[3]. This paper is to gain understanding of the mentioned changes in a populated riparian zone because this would allow people to identify, proactively address specific concerns and monitor changes over time.

Riparian zones are the interfaces between terrestrial and aquatic ecosystems, and host a wide array of plant and animal life [4]-[6]. Understanding of terrestrial-aquatic interactions is critical for assessing ecological effects of development because human settlements are often clustered near such areas [7] [8]. Environmental 
changes caused by human activities are often agent of perturbation in these systems [9].

\section{Study Site}

Located at the eastern edge of Kuching city, the study site is near Muara Tabuan Light Industrial Park. The industrial park is beside the confluence point of tidally-influenced Tabuan and Kuap Rivers (Figure 1). Earliest development of this area was traced to 1978 with the construction of a manufacturing plant, followed by housing estates and villages nearby. It was once a nipah swamp, characterized by nipah palms or Nypa fruticans lining the banks of Kuap River. For over 35 years, the nipah swamps along the two rivers are subjected to human interventions [10]. It is for this reason that makes this area an ideal site to have an investigation on its characteristics. A total of 22 polygons of $100 \mathrm{~m} \times 100 \mathrm{~m}$ are delineated along the riparian strip for analysis. Some intact nipah swamps are still thriving on the opposite bank of the industrial park, allowing comprehensible comparison to the polygons being studied.

\section{Field Investigation}

Borneo Island is one of the many islands dotted the western Indo-Pacific region. As such, the typical mangrove zones depicted in Figure 2 holds true for the study site [11]. The site is located about $18 \mathrm{~km}$ from the estuary to South China Sea, making it categorized as landward zone of mangrove habitat. In the case of Kuap River, Nypa fruticans which is indigenous to this region [12] dominates the water edges (Figure 3). In its most pristine conditions, they form unbroken swampland, often stretch miles into the land. Having said so, it is also known there

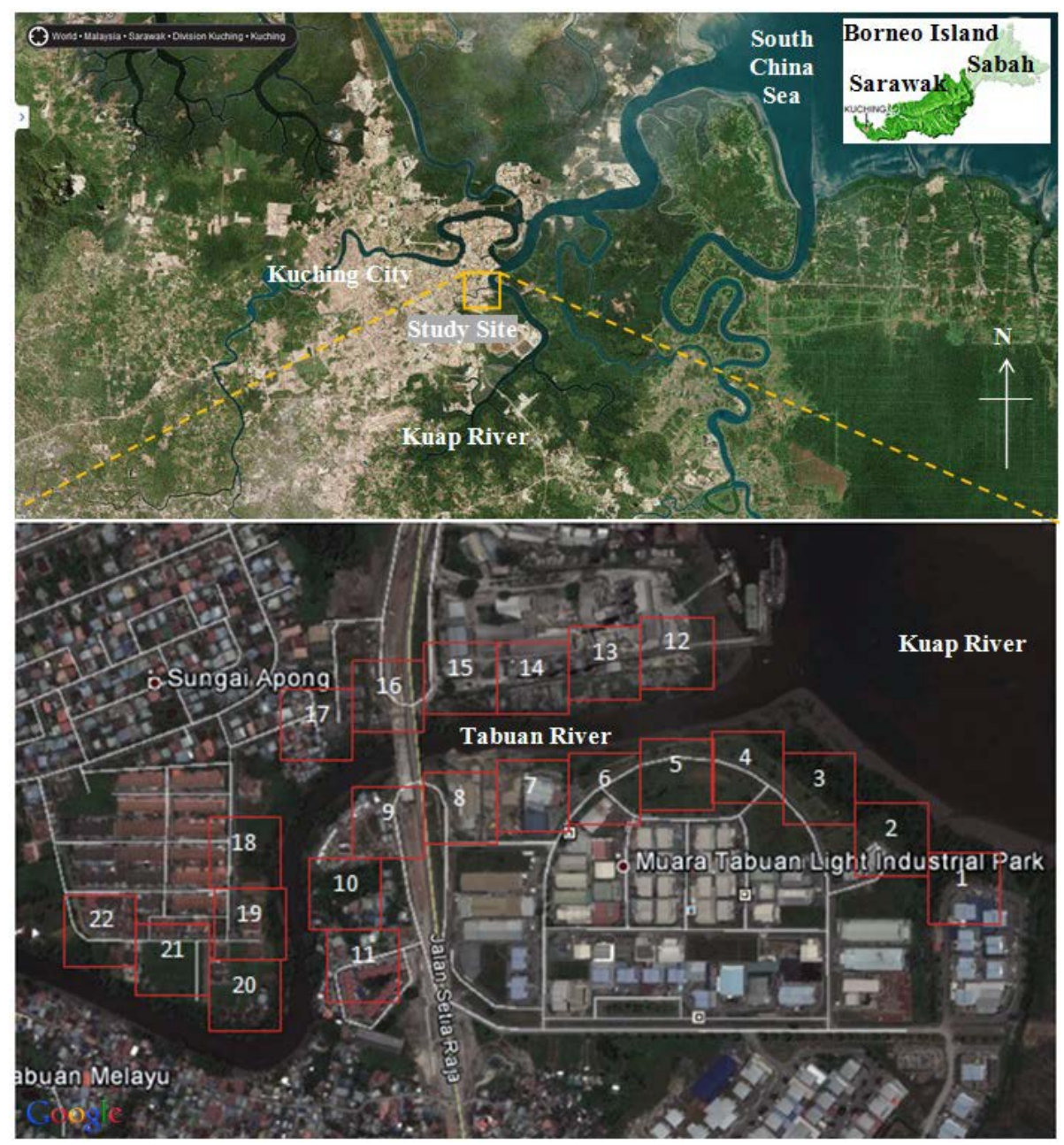

Figure 1. Overview of the study site. 


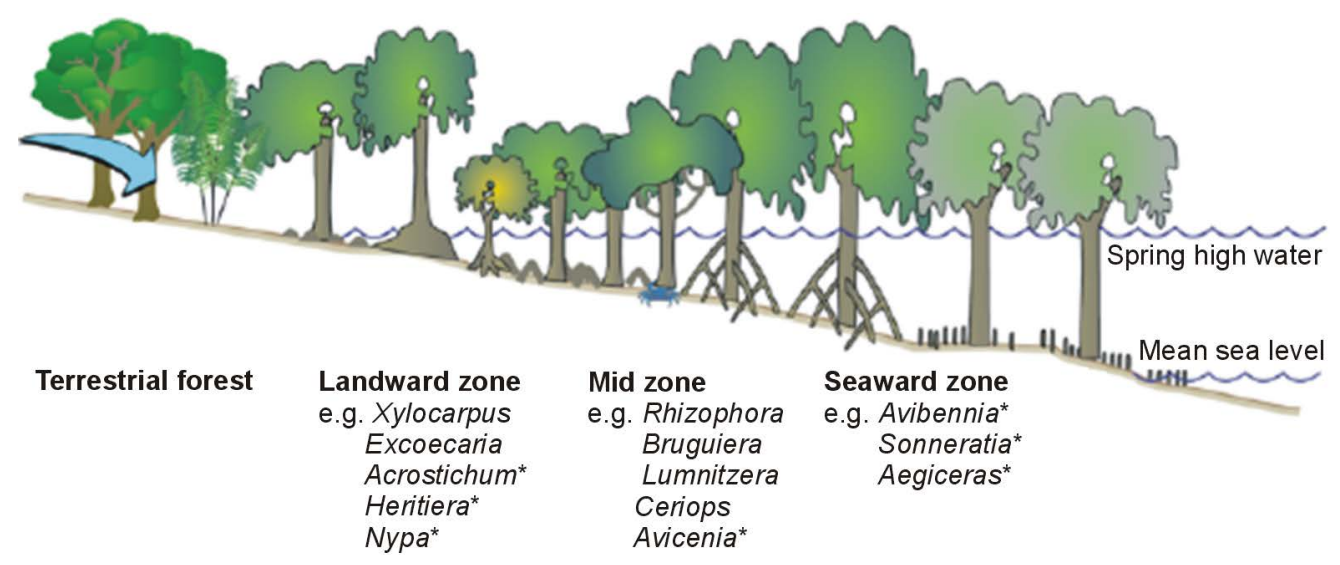

* Occurs in the western Pacific only.

Figure 2. Typical three zones of mangrove habitats in the Tropical Pacific [11].

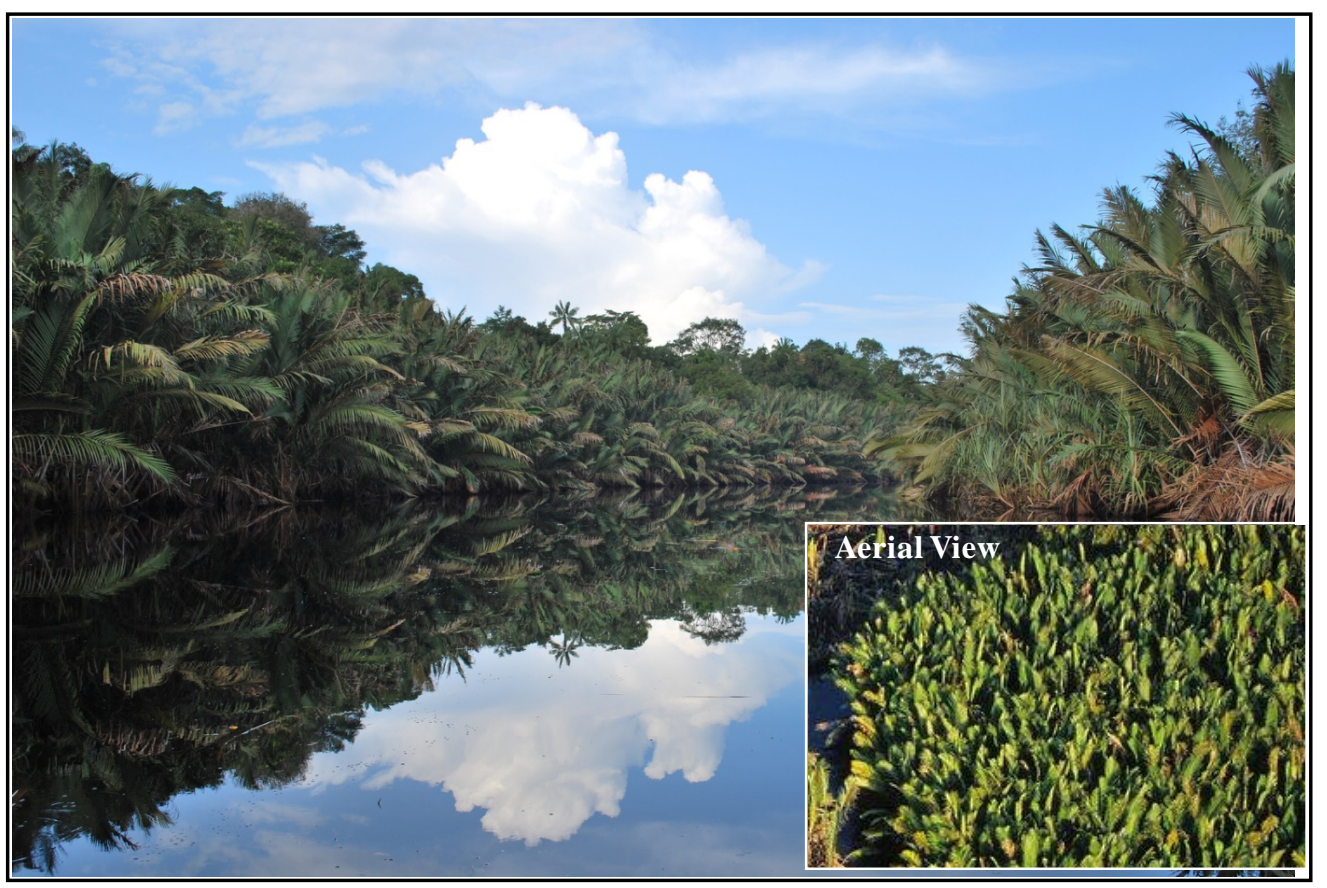

Figure 3. Nipah swamp in pristine conditions.

is no clear boundary for wetland species. Sometimes, other species are found occasionally intermingling with nipah palms along river banks.

Nipah palms grow in soft mud and uniquely in river stretches with a mix of low salinity, regular inflow of freshwater and nutritious silt. The plants are less salt tolerant than mangroves and often occur in pure stands of nipah swamp/forest. Its ability to withstand slight salt water gives them an advantage to flourish in between freshwater and salt water ecosystems. It can tolerate infrequent inundation, so long as the soil does not dry out for too long. Its horizontal creeping stem stabilises river banks preventing soil erosion. New fronds emerge quickly after damage and so quickly protect the land after storms and also continuously produce useful products for the locals [13]-[15].

The conditions of riparian vegetation reflect the influence of human activities in the riparian zones [16] that often devastating the vegetation (Figure 4). A measurement of vegetation cover in the outlined 22 polygons points to the fact, not surprising that the once governing nipah palms are only found in small pockets (Figure 5). Percentage and lushness of nipah palm in each polygon are obtained for the assessment (Table 1). This is 
achieved through a series of air photo inspections [17], in which the feather-like nipah leaves give a distinctive texture that easily indefinable and measurable of its coverage. Otherwise, it is rather difficult to differentiate other forms of vegetation.

Through field trips, the conditions of the site are more clearly observed and documented. What cannot be defined through air photos is assisted by field trips to reveal that the riparian zones are dominated by Sonneratia caseolaris, normally categorized as mangrove species. Photos depicting the conditions of the riparian zone under study are supplemented in the appendices. We perceive that human activities spanning over 35 years have induced the nipah palm to taper off and lead to event of taking over by other species.

Similar to Nypa fruticans, Sonneratia caseolaris is also indigenous to this region. Naturally, the plant is found in lower saline areas on deep muddy soil along tidal creeks with slow moving freshwater. As a pioneering species that colonizes newly formed mudflats, it was reported to expand rapidly in number, especially in optimum conditions of low salinity [18] [19]. It is fast growing with low seed viabililty (sets fruit only three months of the year). This species can grow up to $30 \mathrm{~m}$ in the center of its range. On the extremities of its range, it grows only to less than $10 \mathrm{~m}$. It is associated with the firefly insect (Ptyeroyx spp.).

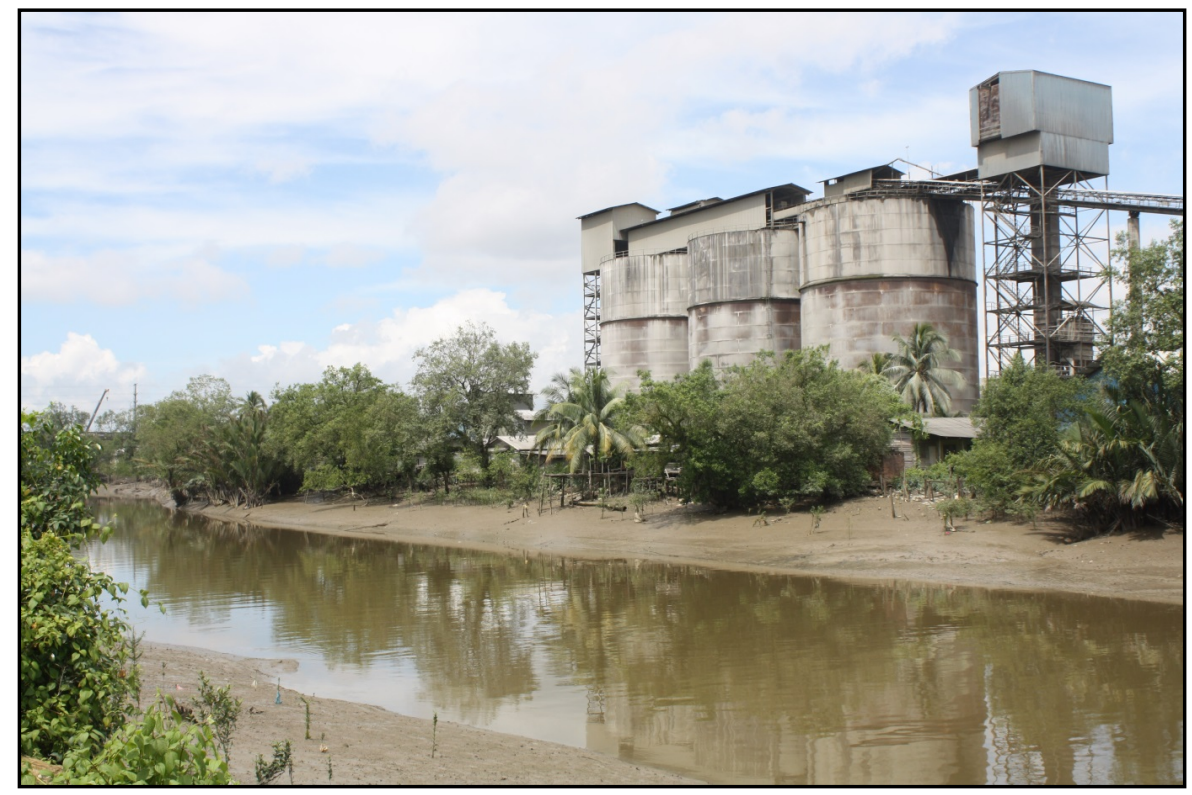

Figure 4. Disturbed nipah swamp beside Tabuan River (Polygons 12 - 15).

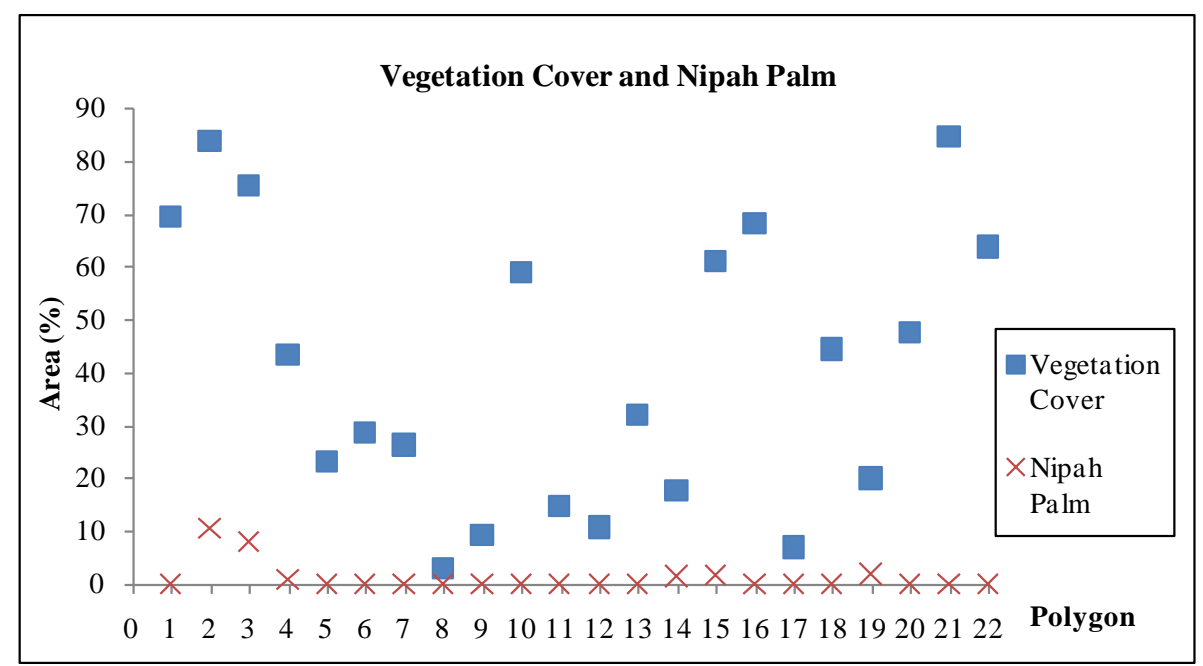

Figure 5. Comparison of vegetation cover and nipah palm. 
Table 1. Measurement in study site.

\begin{tabular}{|c|c|c|c|c|}
\hline Polygon & Vegetation Cover (\%) & Nipah Palm (\%) & Lushness of Nipah Palm & Remarks \\
\hline 1 & 69.54 & 0 & - & $\mathrm{i}$ \\
\hline 2 & 83.84 & 10.41 & Yes & $\mathrm{i}$ \\
\hline 3 & 75.25 & 7.86 & Yes & $\mathrm{i}$ \\
\hline 4 & 43.27 & 0.76 & Yes & $\mathrm{i}$ \\
\hline 5 & 23.03 & 0 & - & ii \\
\hline 6 & 28.51 & 0 & - & ii \\
\hline 7 & 26.31 & 0 & - & ii \\
\hline 8 & 3.02 & 0 & - & ii \\
\hline 9 & 9.14 & 0 & - & ii \\
\hline 10 & 58.85 & 0 & - & ii \\
\hline 11 & 14.76 & 0 & - & ii \\
\hline 12 & 10.7 & 0 & - & $\mathrm{i}$ \\
\hline 13 & 31.96 & 0 & - & $\mathrm{i}$ \\
\hline 14 & 17.56 & 1.45 & No & $\mathrm{i}$ \\
\hline 15 & 60.9 & 1.51 & No & $\mathrm{i}$ \\
\hline 16 & 68.09 & 0 & - & ii \\
\hline 17 & 6.95 & 0 & - & $\mathrm{i}$ \\
\hline 18 & 44.31 & 0 & - & $\mathrm{i}$ \\
\hline 19 & 19.91 & 1.91 & Yes & i \\
\hline 20 & 47.6 & 0 & - & $\mathrm{i}$ \\
\hline 21 & 84.54 & 0 & - & $\mathrm{i}$ \\
\hline 22 & 63.7 & 0 & - & $\mathrm{i}$ \\
\hline
\end{tabular}

${ }^{\mathrm{a} N i p a h ~ p a l m s ~ a m o n g ~ t h e ~ v e g e t a t i o n ~ c o v e r ; ~ i . ~ A p p e a r a n c e s ~ o f ~ S o n n e r a t i o ~ c a s e o l a r i s ; ~ i i . ~ H e a v y ~ h u m a n ~ d i s t u r b a n c e s ~ a r o u n d ~ t h e ~ a r e a . ~}$

\section{Discussion}

Nypa fruticans is portrayed as a dominant species in natural ecosystems. The followings are reports from the same region of Southeast Asia. Reference [20] wrote about the mangroves in Mahakam Delta of East Kalimantan, Indonesia that the sedimentation zones were colonized first by Sonneratia caseolaris, which soon gave way to a fairly varied formation dominated by Avicennia sp. This species was gradually replaced by ferns (Acrostichum), or by Nypa fruticans which covered most of the delta.

Reference [21] stated that Nypa fruticans was colonizing along most rivers in Kemaman, Terengganu, Malaysia and generally grows gregariously but not extensively, interspersed with Avicennia species and Sonneratia species near the river mouth and with Rhizophora species and Bruguiera species on soft mud further inland. Reference [22] described a mixture of Sonneratia caseolaris and Nypa fruticans alongside other mangrove species in the marine and brackish stretches of Tutong River, Brunei.

We notice, contrary to the previous reports, the number of Nypa fruticans in the study site is dwindling and Sonneratia caseolaris is overtaking the palms when implicated by high human disturbances. This is most significant in Polygons 8, 9, 16 and vicinity, where an expansion works of the bridge was carried out for the past three years, see no signs of the palm but dominate by Sonneratia caseolaris instead. Reference [23] reported that Sonneratia caseolaris was fairly well adapted to freshwater. Here, we suggest that the plant also has high resistance towards human disturbances. We also add to the statements of [21] that Sonneratia caseolaris behaves intrusively rather than neighbourly in disturbed systems, as exemplify in Figure 6 and Appendix (Polygons 18 22). This is a growing behaviour contradictory to reports of Sonneratia caseolaris in natural systems. 


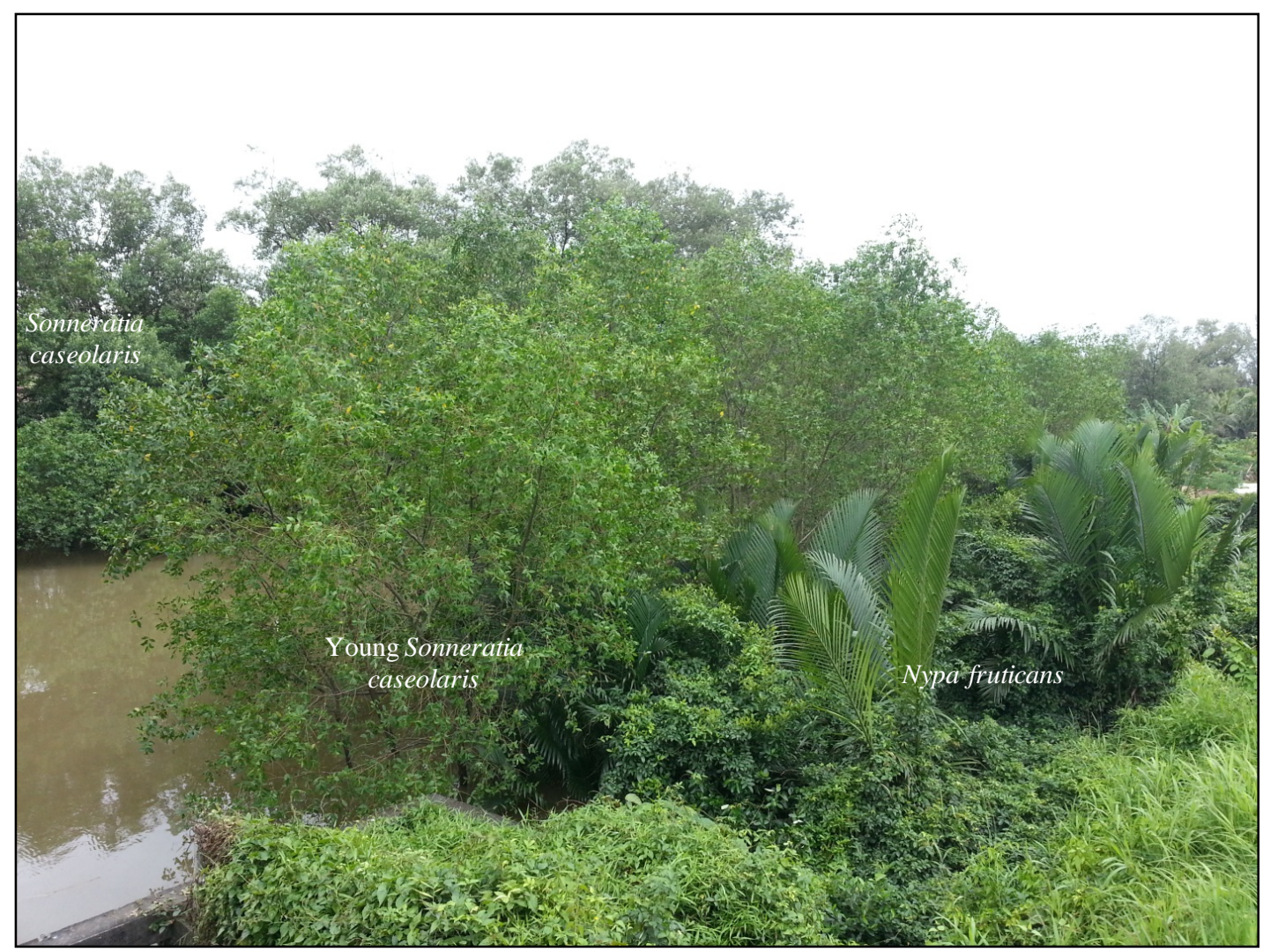

Figure 6. Intermingle of Nypa fruticans and Sonneratio caseolaris (Polygon 19).

\section{Conclusion}

Nypa fruticans is common over Southeast Asia. Locals always consider that the palms are aplenty and hardy, with little attention showers over their wellbeing. Somehow, observation from this study shows the opposite. Once a stronghold region of nipah swamp is slowly faded away, the study site is being replaced by Sonneratia caseolaris - a mangrove system. In the viewpoint of water course management, both plants are superior in maintaining the structures of river banks, but losing one system over another is a trade-off to be reckoned of. This should sound an alarm that even abundance of one plant does not guarantee the continuity of the species in the face of human disturbances.

\section{Acknowledgements}

Special thanks to Allan Pui Pei Ping, Chan Huan Chyi, Chong Pei Fong, Jacky Kong, Jennifer Chong Fui Khiun, Liew Kien Hung, Lau Chung Xien, Lau Pei Ching, Lester Shoon Wei Jim and Wong Xuan Yuan for assisting in field trips.

\section{References}

[1] Hobbs, R.J., Arico, S., Aronson, J., Baron, J.S., Bridgewater, P., Cramer, V.A., Epstein, P.R., Ewel, J.J., Klink, C.A., Lugo, A.E., Norton, D., Ojima, D., Richardson, D.M., Sanderson, E.W., Valladares, F., Vilà, M., Zamora, R. and Zobel, M. (2006) Novel Ecosystems: Theoretical and Management Aspects of the New Ecological World Order. Global Ecology and Biography, 15, 1-7. http://dx.doi.org/10.1111/j.1466-822X.2006.00212.x

[2] Lindenmayer, D.B., Fischer, J., Felton, A., Crane, M., Michael, D., Macgregor, C., Montague-Drake, R., Manning, A. and Hobbs, R.J. (2008) Novel Ecosystems Resulting from Landscape Transformation Create Dilemmas for Modern Conservation Practice. Conservation Letters, 1, 129-135. http://dx.doi.org/10.1111/j.1755-263X.2008.00021.X

[3] Bridgewater, P., Higgs, E.S., Hobbs, R.J. and Jackson, S.T. (2011) Engaging with Novel Ecosystems. Frontiers in Ecology and the Environment, 9, 423-423. http://dx.doi.org/10.1890/1540-9295-9.8.423 
[4] Channey, E., Elmore, W. and Platt, W.S. (1990) Livestock Grazing on Western Riparian Areas. US Environmental Protection Agency, Washington DC.

[5] Gregory, S.V., Swanson, F.J., McKee, W.A. and Cummins, K.W. (1991) An Ecosystem Perspective of Riparian Zones. Bioscience, 41, 540-551. http://dx.doi.org/10.2307/1311607

[6] Johnson, R.R., Haight, L.T. and Simpson, J.M. (1997) Endangered Species vs Endangered Habitats: A Concept. In: Johnson, R.R. and Jones, D.A., Eds., Importance, Preservation and Management of Riparian Habitat: A Symposium, USDA Forest Service General Technical Report RM-43, Ft. Collins, CO., 68-79.

[7] Schnaiberg, J., Riera, J., Turner, M.G. and Voss, P.R. (2002) Explaining Human Settlement Patterns in a Recreational Lake District: Vilas County, WI, USA. Environmental Management, 30, 24-34. http://dx.doi.org/10.1007/s00267-002-2450-z

[8] Walsh, S.E., Soranno, P.A. and Rutledge, D.T. (2003) Lakes, Wetlands and Streams as Predictors of Land Use/Cover Distribution. Environmental Management, 31, 198-214.

[9] Richardson, D.M., Holmes, P.M., Esler, K.J., Galatowitsch, S.M., Stromberg, J.C., Kirkman, S.P., Pyšek, P. and Hobbs, R.J. (2007) Riparian Vegetation: Degradation, Alien Plant Invasions and Restoration Prospects. Diversity and Distribution, 13, 126-139. http://dx.doi.org/10.1111/j.1366-9516.2006.00314.x

[10] Polidoro, B.A., Carpenter, K.E., Collins, L., Duke, N.C., Ellison, A.M., Ellison, J.C., Farnsworth, E.J., Fernando, E.S., Kathiresan, K., Koedam, N.E., Livingstone, S.R., Miyagi, T., Moore, G.E., Nam, V.N., Ong, J.E., Primavera, J.H., Salmo III, S.G., Sanciangco, J.C., Sukadjo, S., Wong, Y. and Yong, J.W.H. (2010) The Loss of Species: Mangrove Extinction Risk and Geographic Areas of Global Concern. PLOS ONE, 5, e10095. http://dx.doi.org/10.1371/journal.pone.0010095

[11] Waycott, M., McKenzie, L.J., Mellors, J.E., Ellison, J., Sheaves, M.T., Coller, C., Schwarz, A-M., Webb, A., Johnson, J.E. and Payri, C.E. (2011) Vulnerability of Mangroves, Seagrasses and Intertidal Flats in the Tropical Pacific to Climate Change. In: Bell, J.D., Johnson, J.E. and Hobday, A.J., Eds., Vulnerability of Tropical Pacific Fisheries and Aquaculture to Climate Change, Secretariat of the Pacific Community, Noumea.

[12] Ashton, E.C. and Macintosh, D.J. (2002) Preliminary Assessment of the Plant Diversity and Community Ecology of the Sematan Mangrove Forest, Sarawak, Malaysia. Forest Ecology and Management, 166, 111-129. http://dx.doi.org/10.1016/S0378-1127(01)00673-9

[13] Tan, H.T.W. (1995) A Guide to the Threatened Plants of Singapore. Singapore Science Centre, Singapore.

[14] Singh, R.S. (1999) Diversity of Nypa in the Indian Subcontinent, Late Cretaceous to Recent. The Palaeobotanist, 48, 147-154.

[15] Ng, P.K.L. and Sivasothi, N. (2001) A Guide to Mangroves of Singapore. Raffles Museum of Biodiversity Research, National University of Singapore and Singapore Science Centre, Singapore.

[16] Elmore, W. and Beschta, R.L. (1987) Riparian Areas: Perceptions in Management. Rangelands, 9, $260-265$.

[17] Kent, D.M. (2001) Applied Wetlands Science and Technology. 2nd Edition, Lewis Publishers.

[18] Panapitukkul, N., Duarte, C.M., Thampanya, U., Kheowvongsri, P., Srichai, N., Geertz-Hansen, O., Terrados, J. and Boromthanarath, S. (1998) Mangrove Colonization: Mangrove Progression over the Growing Pak Phanang (SE Thailand) Mud Flat. Estuarine, Coastal and Shelf Science, 47, 51-61. http://dx.doi.org/10.1006/ecss.1998.0343

[19] Leung, J.Y.S. and Tam, N.F.Y. (2013) Influence of Plantation of an Exotic Mangrove Species, Sonneratia caseolaris (L.) Engl., on Macrobenthic Infaunal Community in Futian Mangrove National Nature Reserve, China. Journal of Experimental Marine Biology and Ecology, 448, 1-9. http://dx.doi.org/10.1016/j.jembe.2013.06.006

[20] Dutrieux, E., Denis, J. and Populus, J. (1990) Application of SPOT Data to a Base-Line Ecological Study of the Mahakam Delta Mangroves (East Kalimantan, Indonesia). Oceanologica Acta, 13, 317-326.

[21] Sulong, I., Mohd-Lokman, H., Mohd-Tarmizi, K. and Ismail, A. (2002) Mangrove Mapping Using Landsat Imagery and Aerial Photographs: Kemaman District, Terengganu, Malaysia. Environment, Development and Sustainability, 4, 135-152. http://dx.doi.org/10.1023/A:1020844620215

[22] Fryar, S.C., Booth, W., Davies, J., Hodgkiss, I.J. and Hyde, K.D. (2004) Distribution of Fungi on Wood in the Tutong River, Brunei. Fungal Divers, 17, 17-38.

[23] Dahdouh-Guebas, F., Jayatissa, L.P., Di Nitto, D., Bosire, J.O., Lo Seen, D. and Koedam, N. (2005) How Effective Were Mangroves as a Defence against the Recent Tsunami? Current Biology, 15, R443-R447. http://dx.doi.org/10.1016/j.cub.2005.06.008 


\section{Appendix}

Air Photo of the Study Site

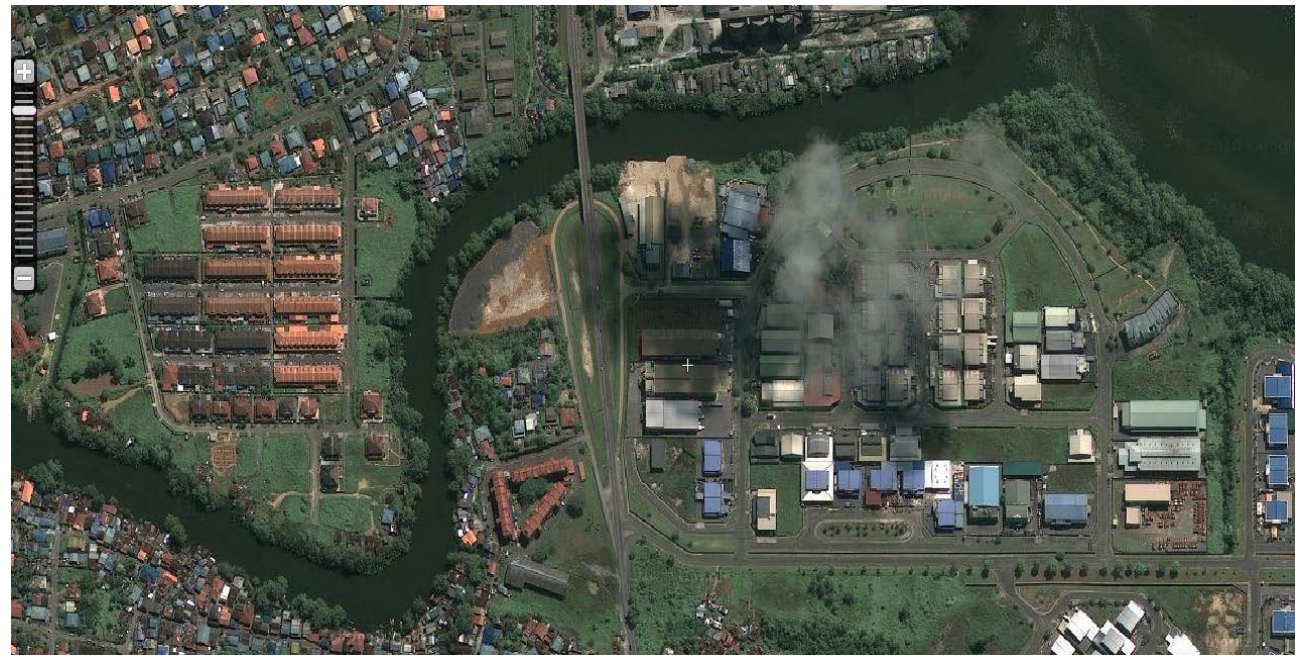

\section{Photos Taken According to Polygons}

\section{Polygon}

$1-4$

\section{Location}

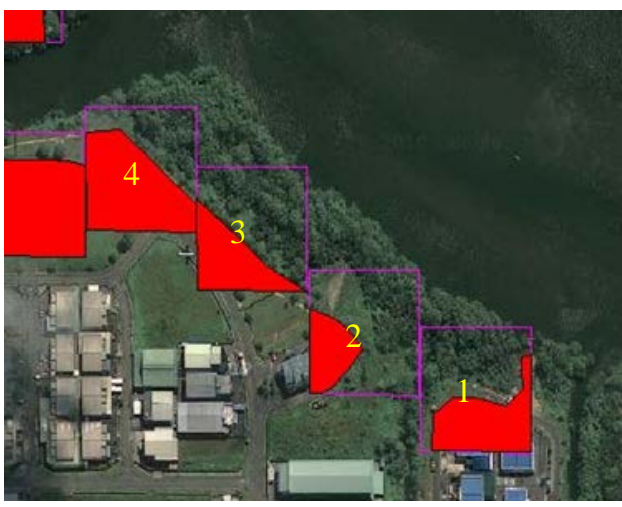

Sonneratia caseolaris dominates the riparian zone

Nypa fruticans is found in small number in Polygons 2, 3 and 4

Note: All photos are taken in 2012-2013

\section{Photos}

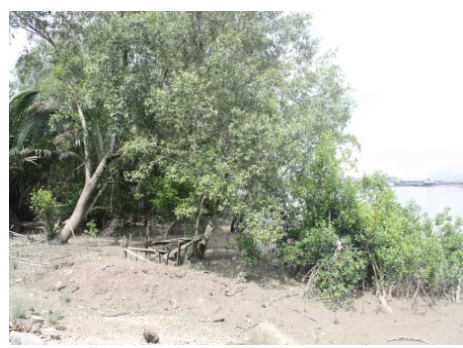

Erosion of river bank and appearance of Sonneratia caseolaris.

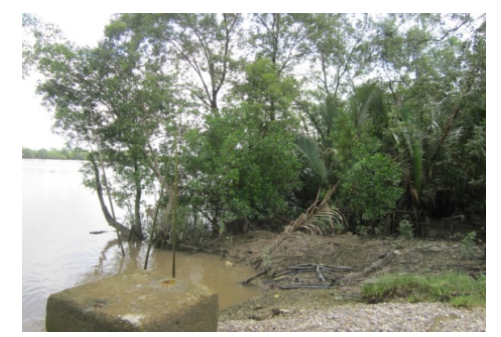

Intermingling of Sonneratia caseolaris and Nypa fruticans. Only a few clumps of Nypa fruticans remain in Polygon 4.

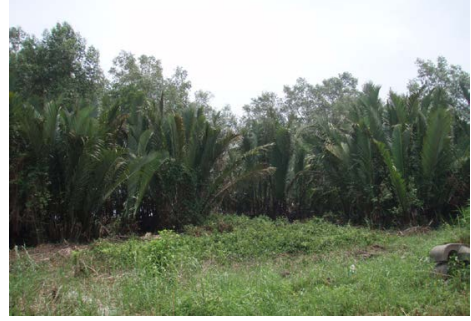

Nypa fruticans in Polygon 2. 


\section{Continued}

5 - 11
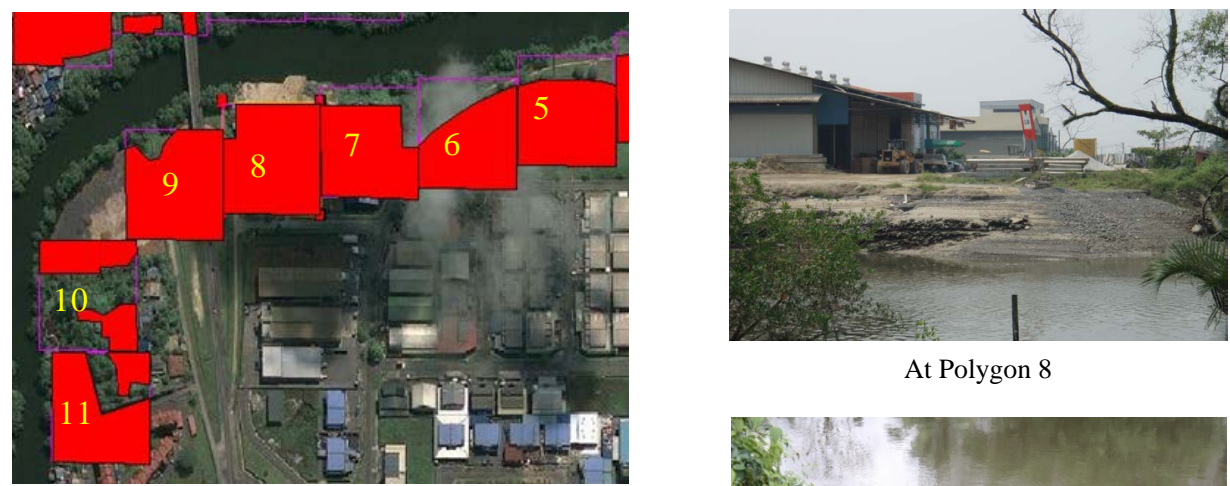

At Polygon 8

Riparian zone is changed to terrestrial

Note: All photos are taken in 2012-2013

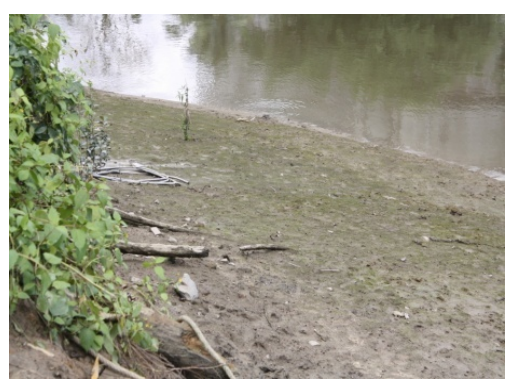

Dried river bank

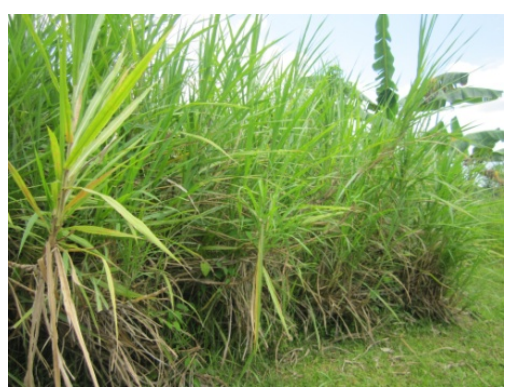

Napier Grass (Pennisetum purpureum)

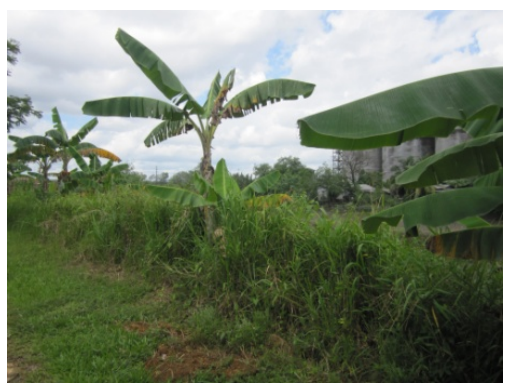

Lalang Grass (Imperata cylindrica)

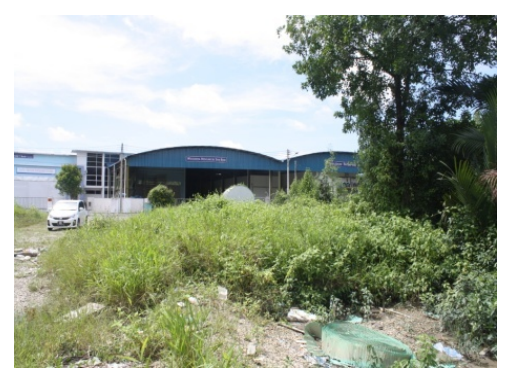




\section{Continued}

$12-17$

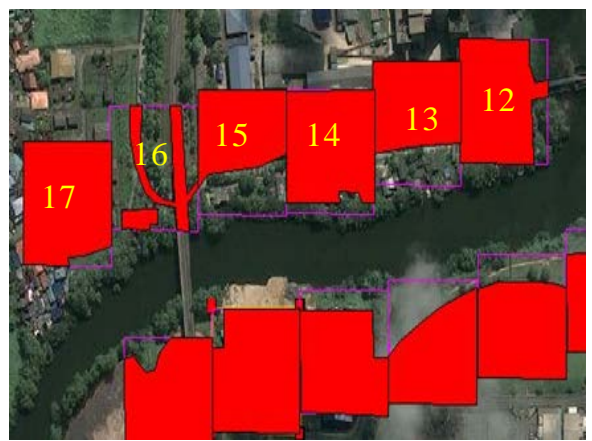

Sonneratia caseolaris dominates the vicinity of the bridge

Nypa fruticans is found in small number in Polygons 14 and 15

Note: All photos are taken in 2012-2013

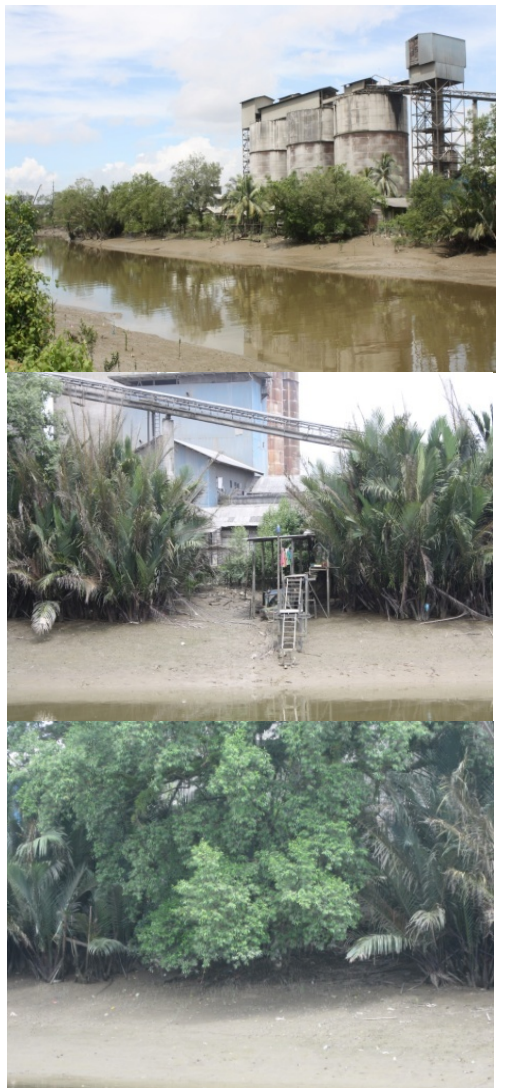

Intermingling of Sonneratia caseolaris and Nypa fruticans. Only a few clumps of Nypa fruticans remain in Polygons 14 and 15.

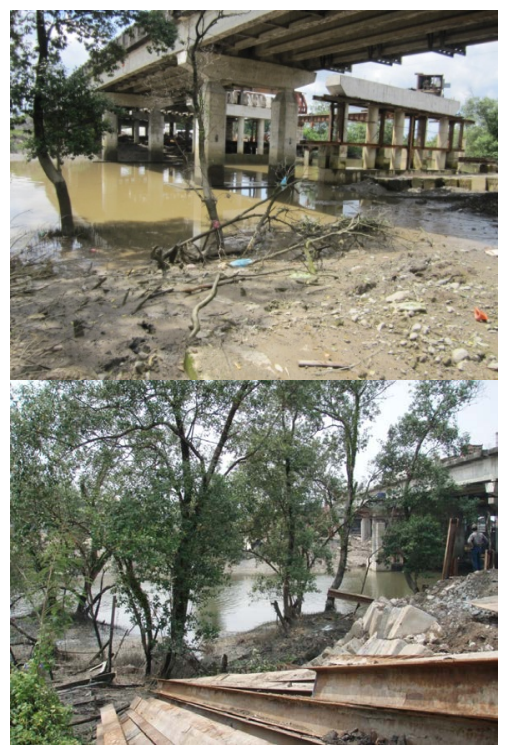

Bridge construction at Polygon 16 Sonneratia caseolaris dominates Polygons 15 , 16 and 17. 


\section{Continued}

$18-22$

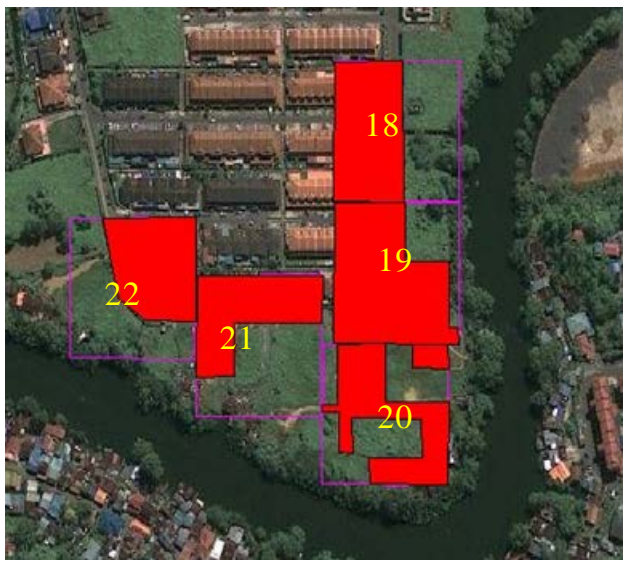

Young Sonneratia caseolaris dominates most of river banks

Nypa fruticans is found in small number in Polygon 19

Note: All photos are taken in 2012-2013

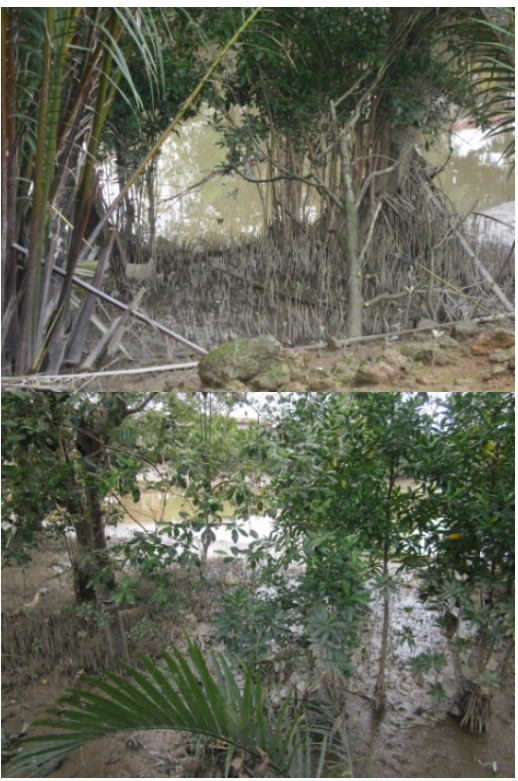

Intermingling of Sonneratia caseolaris and Nypa fruticans. Only a few clumps of Nypa fruticans remain in Polygon 19.

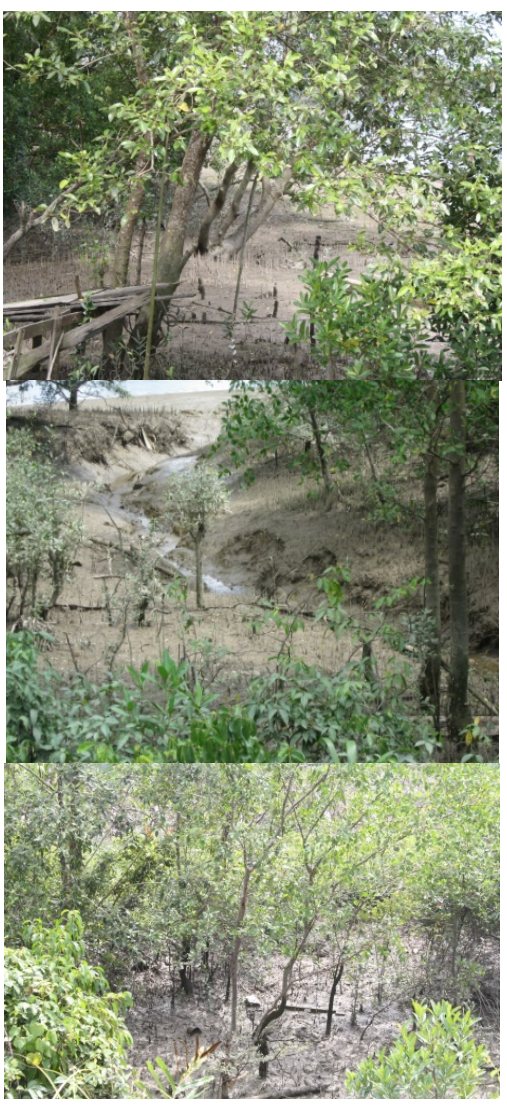

Sonneratia caseolaris dominates most of the river banks. 
Scientific Research Publishing (SCIRP) is one of the largest Open Access journal publishers. It is currently publishing more than 200 open access, online, peer-reviewed journals covering a wide range of academic disciplines. SCIRP serves the worldwide academic communities and contributes to the progress and application of science with its publication.

Other selected journals from SCIRP are listed as below. Submit your manuscript to us via either submit@scirp.org or Online Submission Portal.
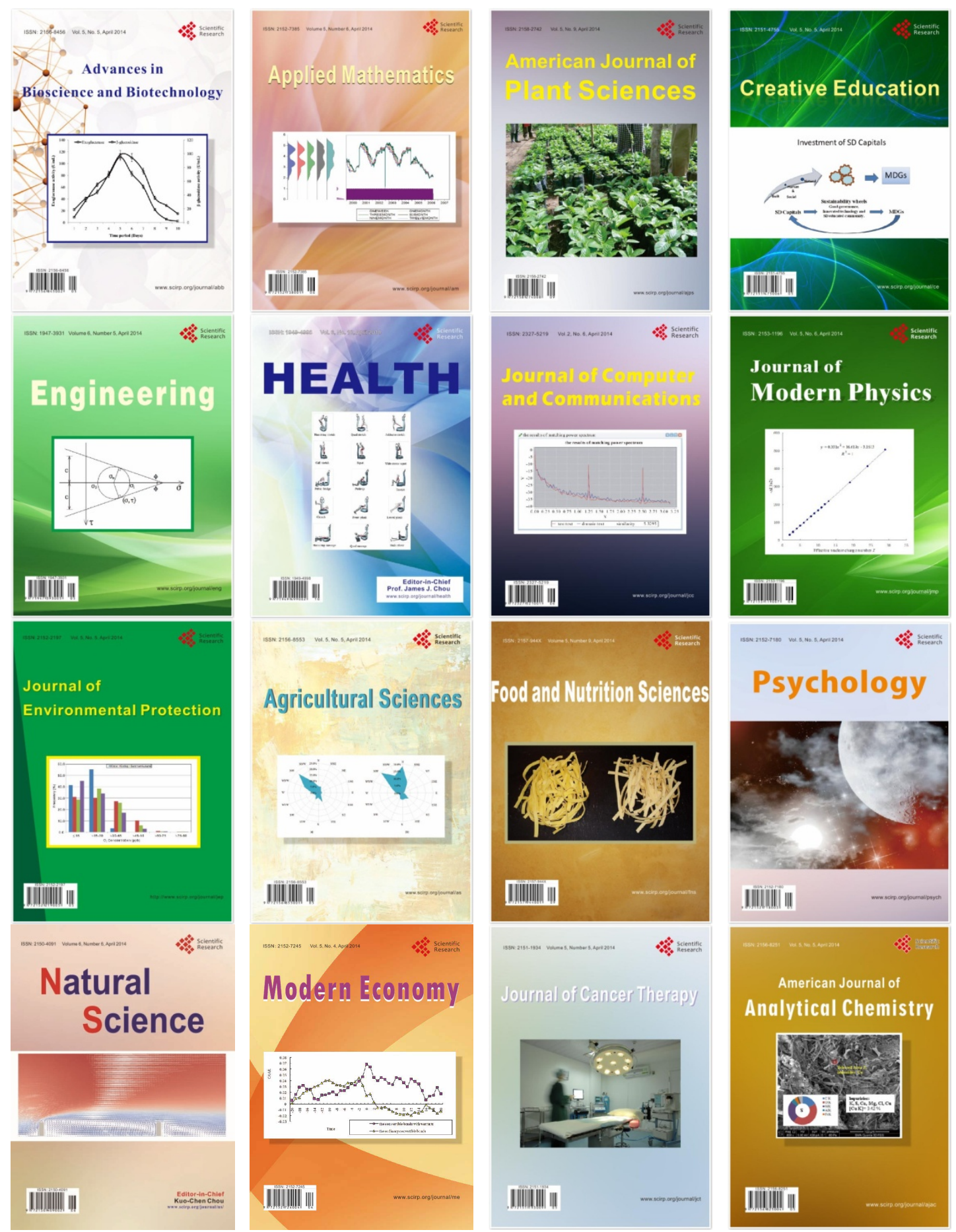